\title{
説
}

J. Jpn. Soc. Colour Mater., 83〔1〕，33-38（2010

\section{特集 界面活性肪(2) -}

\section{化粧品製剂における界面活性剤の効果的な活用方法}

本報では一次乳化に高圧ホモジナイザーを用いた微細 $\mathrm{O} / \mathrm{W}$ 型エマルションを用いることで親水性界面活性剂の配合量を極力 抑え，O/W/O型エマルションの安定性を向上可能であることを解説した。さらに高分子界面活性剂である Polyoxyethylene (30) dipolyhydroxystearate (PEDS) を用いて, O/W/O 型エマルションと油および粒子径の異なる複合エマルションである $\left(\mathrm{O}_{1}+\mathrm{O}_{2}\right) / \mathrm{W}$ 型エマルションとを組み合わせた新しい $\left(\mathrm{O}_{1}+\mathrm{O}_{2}\right) / \mathrm{W} / \mathrm{O}_{3}$ 型エマルションを調製し，内包した油溶性成分のコントロールリリー スが可能であることを論じ，O/W/O型エマルションにおける効果的な界面活性剤の活用法について解説した。

\section{1.はじめに}

乳化とは一般的に互いに混ざり合わない油と水の一方が，他 方の中に微小な液滴として分散する現象1)である。乳化には界 面活性剂が用いられており, 化粧品分野では非イオン性界面活 性剂を中心としさまざまな種類が使用されている。乳化手段と しては凝集法 (化学的乳化) と分散法 (機械的乳化) の2 種類が ある。凝集法は界面化学的特性を利用する方法で, 実際の乳化 法としては反転乳化法 ${ }^{2)}$, 転相温度乳化法 (PIT 温度乳化法) ${ }^{3-6)}$, 液晶乳化法 ${ }^{7-9)}$ やD 相乳化法 ${ }^{10,11)}$ などがある。一方, 分散法は 機械力を利用して乳化粒子を得る方法で, 高速剪断力を有する ホモミキサー, ディスパーミキサー, ウルトラミキサー, 高圧 ホモジナイザー（マイクロフルイダイザー）やフィルミックス などが用いられている。実際の化粧品分野においては凝集, 分 散法をそれぞれ使い分ける場合と, 両者を複合化する場合があ る。この方法はとくに複雑で系の安定化が難しい多相エマルシ ヨンの調製時に効力を発揮する。

多相エマルションは, 水相中にW/O 型エマルションが分散し たW/O/W 型エマルションと, 油相中に $\mathrm{O} / \mathrm{W}$ 型エマルションが 分散した $\mathrm{O} / \mathrm{W} / \mathrm{O}$ 型エマルションが存在する。W/O/W 型エマル ションの研究は, 1925 年にSifrizが報告 ${ }^{12)}$ して以来, 1960年代 から盛んになり, 化学分野で液膜分離への応用, 薬学分野で は, MulleyらによりDDSへの応用が示唆された ${ }^{13)} 。 一$ 方, O/W/O 型エマルションの研究は, 医薬品分野における有効成分 の徐放化 ${ }^{14,15)}$, 酵素の固定化 ${ }^{16)}$ などが報告されている。多相 エマルションは, 感触, 有効成分の安定化拉よびその浸透性を

\footnotetext{
受付日：2009年 8 月 4 日 受理日：2009年10月 27 日

Approach in the Effective Use of Surfactant for Cosmetic Formulation Hitoshi IMAMURA *,†

*ポーラ化成工業株式会社

神奈川県横浜市神奈川区高島台27-1（†221-0833）

$\dagger$ Corresponding Author, E-mail : imamura@pola.co.jp
}

高めるなど，O/W 型，W/O 型エマルションにはない新たな性質 およびそれに伴う新たな特性の発現が期待される。しかし，製 剤の安定化が難しく，多相エマルションを調製するためには， 数種の界面活性剤を効果的に使用し，かつ機械力をうまく利用 する必要がある。本報ではとくに $/$ /W/O型エマルションについ て言及する。

\section{2. $\mathrm{O} / \mathrm{W} / \mathrm{O}$ 型エマルションの調製}

\section{$2.10 / \mathrm{W} / \mathrm{O}$ 型エマルションの調製法}

$\mathrm{O} / \mathrm{W} / \mathrm{O}$ 型エマルションの調製法には，1段階乳化法，2段階 乳化法がある。1段階乳化法は, 一度の乳化工程で多相エマル ションが得られる方法である。この場合，内相と最外相は同一 の組成であり，各相の比率は使用する界面活性剤や油の種類に より決まる17)。

一方，2段階乳化法は，あらかじめ調製したエマルション (一 次乳化) を最外相となる液体中に分散 (二次乳化) することで得 られる。この場合，一次乳化時に粒子径を極力小さくすること および二次乳化時には一次乳化物を破壊しないために剪断力を 小さくする必要がある。しかし，各相の組成比が 1 段階乳化法 よりも自由にコントロールできること, 内相比の高い多相エマ ルションが再現良く調製できること，界面活性剤を界面に効率 良く吸着できるために安定性を確保しやすい等のメリットがあ り，多用されている。また， O/W/O型エマルションを調製する

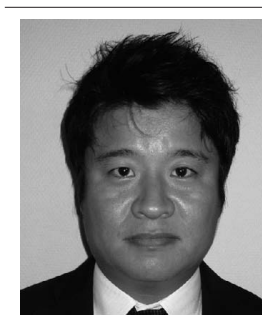

〔氏名〕いまむらひとし

〔現職〕ポーラ化成工業(株) スキンケア開発部 主任研究員 博士 (工学)

〔掫味〕写真, 自転車

〔経歴〕1998年3月東京理科大学大学院理工学 研究科工業化学専攻修士課程修了。 1998 年 4 月ポーラ化成工業(株)入社。 2005 年 3 月東京理科大学大学院理工学 研究科博士後期課程修了。現在に至る。 
ために用いる界面活性剤は以下の点に注意して使用する必要が ある。

（i）親油性界面活性剤が安定性の良好な W/O 型エマルションを 調製可能であること

（ii）親水性界面活性剂のHLBが 15 以上

(iii) 一次乳化に使用する界面活性剂量をなるべく少なくする

2.2 マイクロフルイダイザー（MFD）について

2.1 項で述べたように安定な $\mathrm{O} / \mathrm{W} / \mathrm{O}$ 型エマルションの調製に は微細な粒子を有する $\mathrm{O} / \mathrm{W}$ 型エマルション (一次乳化物) を調 製する必要がある。一次乳化時に凝集法を用いて粒子径を小さ くすることができるが, 凝集法のみで乳化を行うとある程度親 水性界面活性剂の量が必要となり, 二次乳化時に不安定化する ことがある。そこで, 一次乳化時に高圧乳化機を用いる方法が ある。

高圧乳化機は 1900 年初頭にフランス人であるオーガスト・ゴ ーリンが牛乳を長期保存するため乳脂肪球を微粒化・均質化す る目的で開発した装置が始まりであると言われている18)。この ゴーリンホモジナイザーは処理物が細管中を $10 〜 50 \mathrm{MPa}$ の圧 力で通過したときに剪断力を与えるものである。これに対し, 最大 $275 \mathrm{MPa}$ とエネルギーレベルが非常に高く, 超微粒子の調 製が可能な高圧ホモジナイザーとして, 米国の Microfluidicsが 開発したマイクロフルイダイザー（MFD）が広く使用されてい る。MFDは, 安定した圧力で処理物をチャンバー, バックプレ ッシャーに供給するインテンシファイヤポンプ, 微細化処理を 行うインタラクションチャンバー, バックプレッシャーモジュ ール, さらには冷却用コイルから構成されている $\left(\right.$ 図-1 $\left.{ }^{19)}\right)$ 。投 入された処理物は特殊なチャンバー内で流路を 2 方向に分けら れた後, 最高 $275 \mathrm{MPa}$ の超高圧でチャンバー内の細管を通過す るため, 処理物は強力な剪断力を受ける。その後, 二つの流路 が再び合流することで強い衝撃力が生じ, さらには高圧で圧縮 された処理物が常圧に戻る際に発生する膨張現象やキャビテー ション効果によって, 粒子径 $0.5 \mu \mathrm{m}$ 以下の微細エマルションの 調製が可能となる20-22)。

2.3 高圧ホモジナイザーを用いた微細エマルションの調製 高圧ホモジナイザーを用いると乳化粒子の微細化が可能とな るが，長期間にわたって安定性を確保することはそれほど容易 ではなく, 界面活性剤や油剤, 水溶性溶媒の種類や量といった 処方構成を最適化する必要がある。

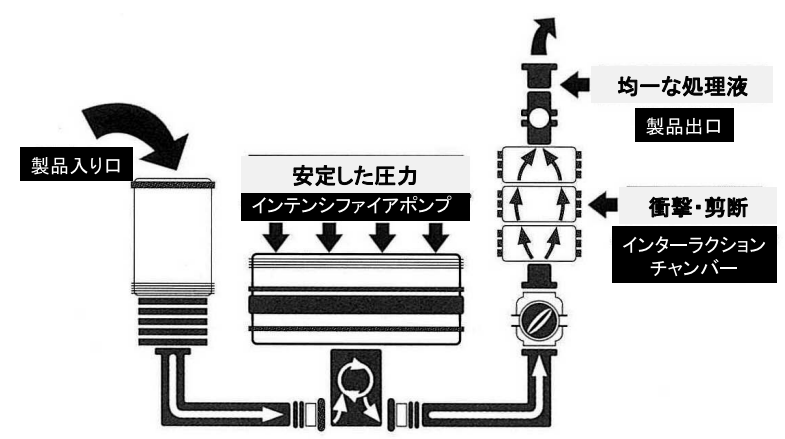

図-1 マイクロフルイダイザーの作動原理（Microfluidizer商 品カタログ資料, みづほ工業株式会社)
坊野らは大豆油, 流動パラフィン, ミリスチン酸イソプロピ ルの三種類の油剤を, 大豆レシチンを用いて高圧乳化を行い, 油剤の種類, 量の変動にともなう粒子径変化を検討するととも に，エタノールやグリセロールの添加が粒子径に与える影響に ついて報告している23)。

中島らは，グリセロールや 1,3 ブチレングリコールなどの水 溶性溶媒を高濃度配合することで界面張力を低下させ，乳化粒 子を効率的に微細化することが可能であると報告している。高 圧ホモジナイザー処理の際，乳化粒子が分裂するのに要する時 間はわずか $0.1 \mathrm{msec}$ 以下であり，界面活性剤が油／水界面へ吸 着する速度よりも速いと推測される。そのため, 界面活性剤よ り水溶性溶媒の界面張力低下効果のほうが優位に機能し, 乳 化粒子の微細化に有効であると考察している ${ }^{24-27) 。 ~}$

以後は一次乳化時に高圧乳化機を用いた $\mathrm{O} / \mathrm{W} / \mathrm{O}$ 型エマルショ ンの調製とその特性について述べる。

\section{3. 高圧乳化機を用いた O/W/O 型エマルションの調製と その特性 28)}

一次乳化時にMFDを用いた超微細 $\mathrm{O} / \mathrm{W}$ 型エマルションを調 製し，これを油に分散させる2段階乳化法を用いた $\mathrm{O} / \mathrm{W} / \mathrm{O}$ 型工 マルションの調製とその分散生成率への影響について述べる。

\section{1 粒子サイズおよび粘度への影響}

O/W/O型エマルションの調製には, 図-2のような2段階乳化法 を用いた。まず，一次乳化として，O/W 型エマルションを $75^{\circ} \mathrm{C}$,

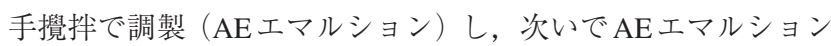
の一部から MFD処理した微細 $\mathrm{O} / \mathrm{W}$ 型エマルション（MEエマル ション）を調製した。調製直後の AEエマルションおよびMEエ

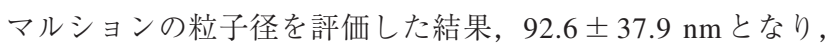
$\mathrm{AE}$ エマルションの $1 / 20$ に減少した（表-1）。このMEエマルシ ヨンを $50 \mathrm{w} / \mathrm{w} \%$ の比率で図-2の調製フローに従ってホモミキサ

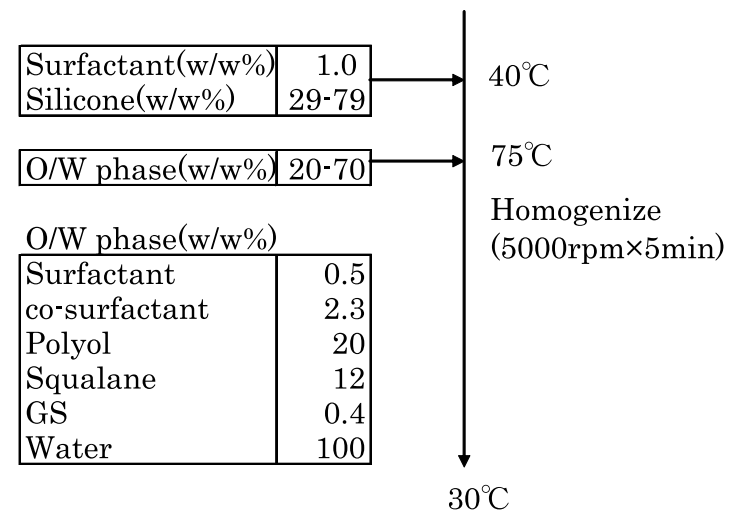

図-2 O/W/O型エマルションの調製方法
表-1 AE，MEエマルションの粒子径

\begin{tabular}{cc}
\hline Emulsion & mean diameter $(\mathrm{nm})$ \\
\hline $\mathrm{AE}$ & $1876.4 \pm 85.1$ \\
$\mathrm{ME}$ & $92.6 \pm 37.9$ \\
\hline
\end{tabular}




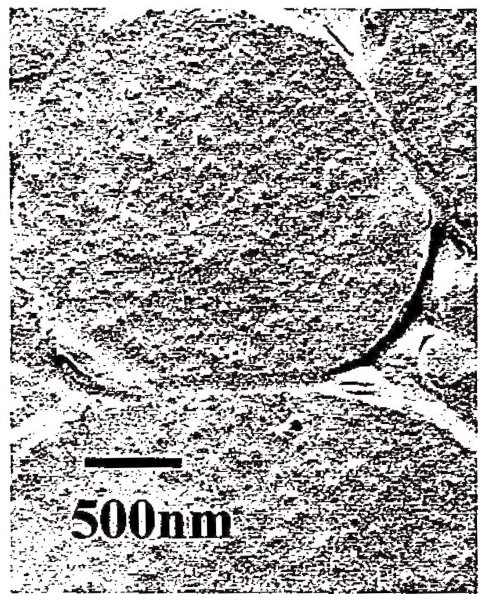

図-3 O/W/O型エマルションの電子顕微鏡（TEM）像

一を用いてデカメチルシクロペンタシロキサン (DMPSi) に分 散し，得られた乳化物をTEMにより観察した（図-3）。その結 果, このエマルションはO/W/O 型エマルションであり, さらに 表-1の MEエマルションの一次粒子と調製後の内相粒子サイズ とがほぼ同等であることを確認した。このことは $\mathrm{O} / \mathrm{W} / \mathrm{O}$ 型エマ ルション調製中にホモミキサーによる粒子の破壊がないことを 示唆している。また $20{ }^{\circ} \mathrm{C}$ の 1 月経時で粒子径の変化は認めら れなかった。

次に $\mathrm{AE}$ およびMEエマルションを用いておのおの別々に図-2 に示す比率で変動させて調製した $\mathrm{O} / \mathrm{W} / \mathrm{O}$ 型エマルションの粘度 值を図-4に示す (AE/O 型エマルション：AEエマルションを用 いて調製した $\mathrm{O} / \mathrm{W} / \mathrm{O}$ 型エマルション，ME/O型エマルション： $\mathrm{ME}$ エマルションを用いて調製した $\mathrm{O} / \mathrm{W} / \mathrm{O}$ 型エマルション)。

その結果二つのエマルション系の粘度変化は同様の傾向を示 した。このことは，O/W/O型エマルションの粘度は内包してい る $\mathrm{O} / \mathrm{W}$ 型エマルションの粒子サイズの影響よりも内包量の影響 を大きく受けることを示唆している。また，O/W/O型エマルシ ヨン比率が $40 \mathrm{w} / \mathrm{w} \%$ 以下では流動性が大きいが, $40 \mathrm{w} / \mathrm{w} \%$ を超 えると粘性が増し，クリーム化の傾向を示した。また $60 \mathrm{w} / \mathrm{w} \%$ を超えると $\mathrm{O} / \mathrm{W} / \mathrm{O}$ 型エマルションは調製できなかった。これは $\mathrm{O} / \mathrm{W}$ 型エマルションの内包量が多くなると親水性界面活性剂の 量が多くなるために生じたと考えられる。

このことから，内包する親水性界面活性剂の量をコントロー ルすることが重要であることがわかる。

\section{2 内相油の最外相油への溶出評価}

内相油として使用しているスクワランの最外相への溶出量を 遠心分離後のガスクロマトグラフィーにより評価した29)。 $\mathrm{ME} / \mathrm{O}$ 型エマルションおよび $\mathrm{AE} / \mathrm{O}$ 型エマルションのスクワラン 溶出量の結果を図-5に示す。両エマルションともに $\mathrm{O} / \mathrm{W}$ 型エマ ルション比率が増えるに従い, 最外相へのスクワラン溶出量が 増加した。この理由は, 内相率が増加しても親油性界面活性剤 量が一定であることから，内相である MEまたは AEエマルショ ンの増加によって界面積が増加したため, エマルションの合一 が促進したものと考えられる。また $\mathrm{ME} / \mathrm{O}$ 型エマルションのス クワラン溶出量が少なかった原因は, DMPSi 中に分散したME エマルションの安定性が高いため，合一が抑制されたものと考

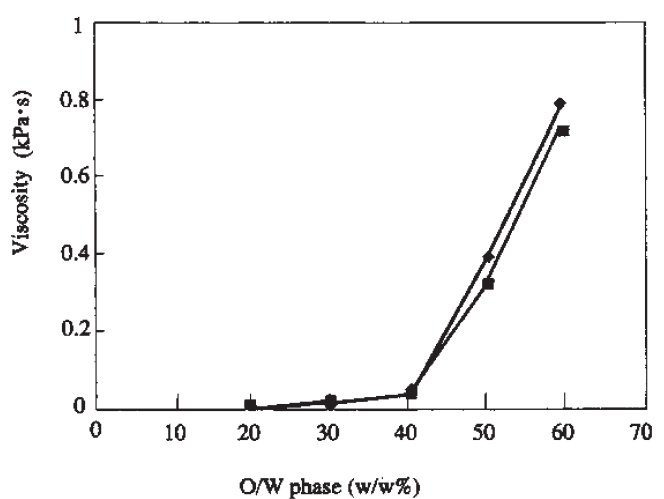

図-4 ME/O 型， $\mathrm{AE} / \mathrm{O}$ 型エマルションの粘度

○: ME/O型エマルション, $\mathbf{a}: \mathrm{AE} / \mathrm{O}$ 型エマルション

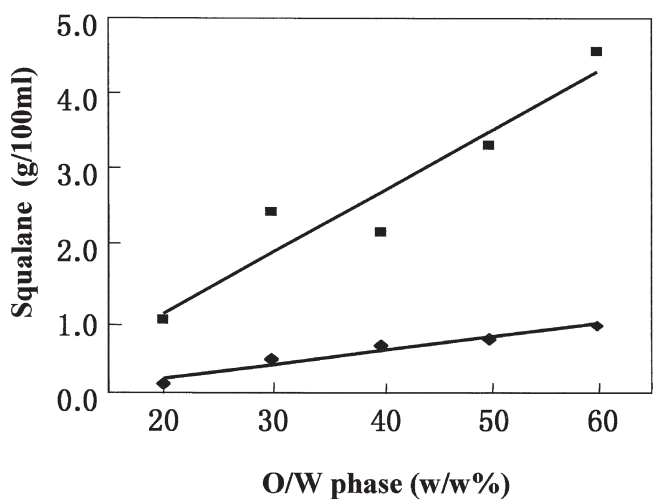

図-5 マイクロフルイダイザー処理による内相油（スクワラ ン）の最外相油への溶出量の変化

•: ME/O型エマルション, ロ: AE/O型エマルション

えられた。

\section{3 分散生成率を用いた安定性評価}

図-6にグリチルレチン酸ステアリル（GS）を指標物質とした ときの ME/O型エマルションおよび $\mathrm{AE} / \mathrm{O}$ 型エマルションの分散 生成率を示す。なお，分散生成率は式（1）により算出した。

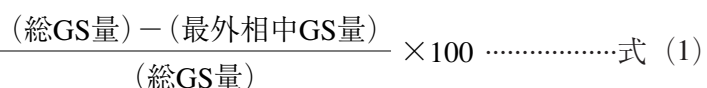

$\mathrm{AE} / \mathrm{O}$ 型エマルションに比ベ $\mathrm{ME} / \mathrm{O}$ 型エマルションの調製直後の 分散生成率が $\mathrm{O} / \mathrm{W}$ 型エマルション比率 $20 \sim 60 \mathrm{w} / \mathrm{w} \%$ の範囲で, 平均 $4 \%$ ほど高い結果であった。この理由としては，MFD処理 により $\mathrm{O} / \mathrm{W}$ 型エマルションの粒子が微細化され，親水性界面活 性剂がより界面に配向しやすくなり，親油性界面活性剂を用い て最外相油中に分散を行う際，親水性界面活性剤の W/O 界面 への影響を抑制したものと考えられる。

次に $20{ }^{\circ} \mathrm{C}$ および $40{ }^{\circ} \mathrm{C} 1$ 力月の分散生成率の変化を図-7に示 す。 $\mathrm{AE} / \mathrm{O}$ 型エマルションの分散生成率は $20^{\circ} \mathrm{C} 1$ 力月経時で調 製後から $10 \%$ 以上低下， $40{ }^{\circ} \mathrm{C} 1$ 力月経時で $25 \%$ 以上低下して おり，そのレベルは両経時ともにAEエマルション比率が高い ほど低下幅が大きい傾向を示した。一方, ME/O型エマルション の分散生成率は, $\mathrm{AE} / \mathrm{O}$ エマルションと同様に $20^{\circ} \mathrm{C}, 40{ }^{\circ} \mathrm{C} 1$ カ 月経時で低下しているものの，低下幅はそれぞれ $20{ }^{\circ} \mathrm{C} て ゙ ~ 8 \% ，$ $40{ }^{\circ} \mathrm{C}$ で $20 \%$ であり, さらにMEエマルション比率の違いによる 


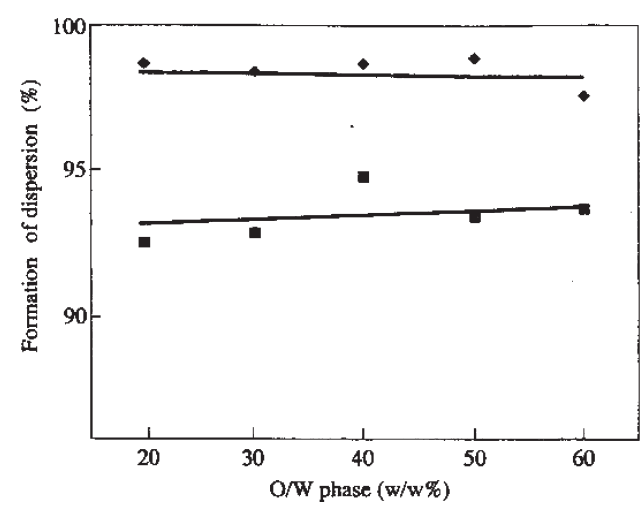

図-6 GS を指標物質とした ME/O 型エマルションと $\mathrm{AE} / \mathrm{O}$ 型 エマルションの分散生成率 $\bullet: \mathrm{ME} / \mathrm{O}$ 型エマルション : $\mathrm{AE} / \mathrm{O}$ 型エマルション

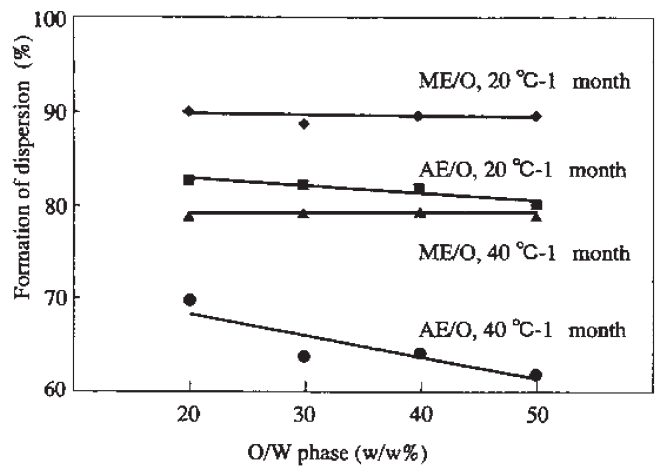

図-7 $20{ }^{\circ} \mathrm{C}$ およ゙゙ $40{ }^{\circ} \mathrm{C} 1$ カ月後の $\mathrm{ME} / \mathrm{O}$ 型エマルションと $\mathrm{AE} / \mathrm{O}$ 型エマルションの分散生成率

低下幅の変化は認められず, ME/O 型エマルションのほうが分 散安定性に優れていることがわかった。この理由として，MFD 処理により $\mathrm{O} / \mathrm{W}$ 型エマルション粒子が微細化され，親水性界面 活性剤がより界面に配向しやすくなった結果，フリーの親水性 界面活性剂が減少し, 油と油に挟まれた $\alpha$ ゲルを介して透過し やすい GS の最外相油への放出が抑制されたものと考えられる。 またMEエマルション比率で分散生成率に変化がないのは, ME エマルション量が増えてもフリーの親水性界面活性剤が増加し ないことが理由として挙げられる。一方, $\mathrm{AE} / \mathrm{O}$ 型エマルショ ンは $\mathrm{AE}$ エマション比率を増加していくに従って，フリーの 親水性界面活性剤が増えたため, GSの放出が増加したと考え られる。

3.2，3.3 項の結果より，内包する $\mathrm{O} / \mathrm{W}$ 型エマルション中の親 水性界面活性剤の量が同じであっても, 界面への配向状態の違 いにより，O/W/O 型エマルションの分散安定性が変化すること がわかる。

\section{4. $\mathrm{O}_{1}+\mathrm{O}_{2} / \mathrm{W} / \mathrm{O}_{3}$ 型エマルションの調製とその特性}

次に異なる 2 種の油 $\left(\mathrm{O}_{1}, \mathrm{O}_{2}\right)$ を用いて別々に調製した $\mathrm{O}_{1} / \mathrm{W}$ 型エマルションと $\mathrm{O}_{2} / \mathrm{W}$ 型エマルションを混合した $\left(\mathrm{O}_{1}+\mathrm{O}_{2}\right) / \mathrm{W}$ 型エマルションについて述べる。

$\left(\mathrm{O}_{1}+\mathrm{O}_{2}\right) / \mathrm{W}$ 型エマルションは系の中で異なる二つの油相を 保持できるという性質がある。一方, これまで述べてきた
表-2 O/W 型エマルションの粒子径

\begin{tabular}{cc}
\hline $\mathrm{O}_{1} / \mathrm{W}$ & $\mathrm{O}_{2} / \mathrm{W}$ \\
\hline $320.1 \pm 89.4 \mathrm{~nm}$ & $617.2 \pm 228.4 \mathrm{~nm}$ \\
\hline
\end{tabular}

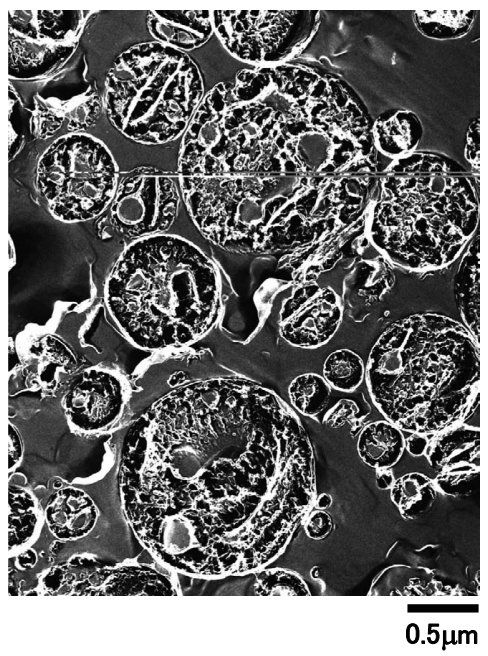

図-8 $\mathrm{O}_{1} / \mathrm{W} / \mathrm{O}_{3}$ 型エマルションのTEM像 $\left(\mathrm{O}_{1} / \mathrm{W}=30 \mathrm{w} / \mathrm{w} \%\right)$

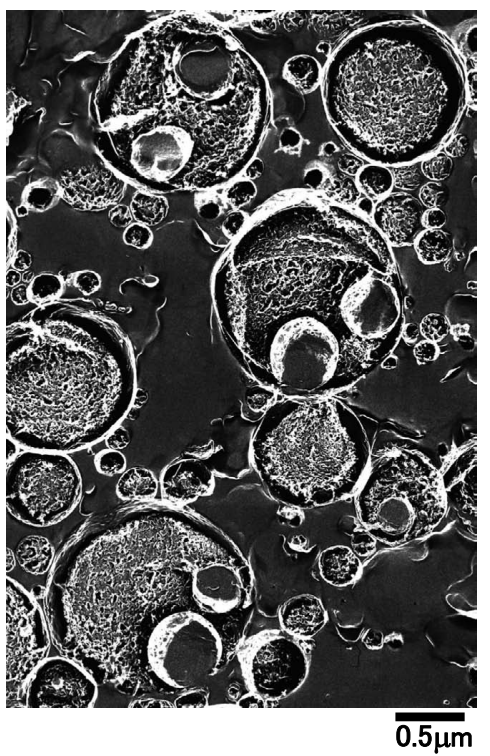

図-9 $\mathrm{O}_{2} / \mathrm{W} / \mathrm{O}_{3}$ 型エマルションのTEM像 $\left(\mathrm{O}_{2} / \mathrm{W}=30 \mathrm{w} / \mathrm{w} \%\right)$

O/W/O型エマルションは, 油溶性有効成分を最内油相に内包す ることで安定化できること，W/O型エマルションと比較して油 を多く配合できること, 皮膚へ塗布した際の伸展性が良いとい った性質も有している。そこで，高分子界面活性剤である Polyoxyethylene (30) dipolyhydroxystearate (PEDS) を用いて, $\mathrm{O} / \mathrm{W} / \mathrm{O}$ 型エマルションと油および粒子径の異なる複合エマルシ ヨンである $\left(\mathrm{O}_{1}+\mathrm{O}_{2}\right) / \mathrm{W}$ 型エマルションとを組み合わせた新しい $\left(\mathrm{O}_{1}+\mathrm{O}_{2}\right) / \mathrm{W} / \mathrm{O}_{3}$ 型エマルションを調製することを試み，その特 性について検討した結果について報告する。

\section{$4.1\left(\mathrm{O}_{1}+\mathrm{O}_{2}\right) / \mathrm{W} / \mathrm{O}_{3}$ 型エマルションの調製}

油として $\mathrm{O}_{1}$ にn-ヘキサデカン $(\mathrm{HD}), \mathrm{O}_{2}$ にホホバ油 $(\mathrm{JO}), \mathrm{O}_{3}$ にメチルフェニルポリシロキサンを用いた。 


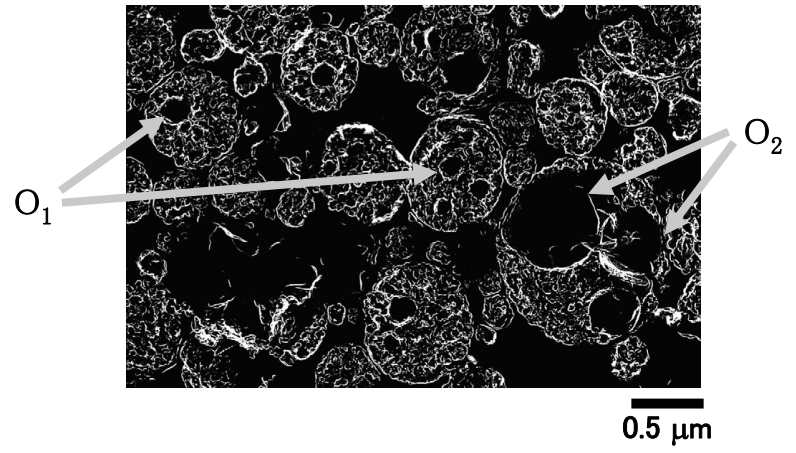

図-10 $\left(\mathrm{O}_{1}+\mathrm{O}_{2}\right) / \mathrm{W} / \mathrm{O}_{3}$ 型エマルションのTEM像

まず，HDを用いて MFD処理した $\mathrm{O}_{1} / \mathrm{W}$ 型エマルション (一次 乳化 1$)$, を調製し, さらにJOを用いて $\mathrm{O}_{2} / \mathrm{W}$ 型エマルション (一次乳化2) を調製した。それぞれのエマルションの粒子径測 定結果を表-2に示す。その結果， $\mathrm{O}_{1} / \mathrm{W}$ 型エマルションの平均 粒子径は $320.1 \pm 89.4 \mathrm{~nm}$ であり, 通常の乳化を行った $\mathrm{O}_{2} / \mathrm{W}$ 型 エマルションは, 平均粒子径 $617.2 \pm 228.4 \mathrm{~nm}$ であった。次に それぞれの一次乳化物を用いて, それぞれ $\mathrm{O} / \mathrm{W} / \mathrm{O}$ 型エマルション を調製し，TEMにより観察を行った(図-8，9）。その結果，TEM 像中の内相油の粒子径と表-2の粒子径がほぼ一致し, 二次乳化 により一次乳化粒子の破壊が生じていないことが確認された。 次に，作製した $\mathrm{O}_{1} / \mathrm{W}$ および $\mathrm{O}_{2} / \mathrm{W}$ を使用し，内相比を $60 \mathrm{w} / \mathrm{w} \%$ に固定し, $5: 1 \sim 1 ： 5$ の割合で変化させ, $\left(\mathrm{O}_{1}+\mathrm{O}_{2}\right) / \mathrm{W} / \mathrm{O}_{3}$ 型 エマルションの調製を行った。

その結果, $\mathrm{O}_{1} / \mathrm{W}: \mathrm{O}_{2} / \mathrm{W}$ の比が $5: 1 \sim 1 ： 1$ の範囲では $\left(\mathrm{O}_{1}+\mathrm{O}_{2}\right) / \mathrm{W} / \mathrm{O}_{3}$ 型エマルションの形成が確認された。図-10に $\mathrm{O}_{1} / \mathrm{W}: \mathrm{O}_{2} / \mathrm{W}$ の比が $3 ： 1$ の場合の TEM 観察像を示す。図より 2 種の一次乳化物の粒子径が保たれたまま $\left(\mathrm{O}_{1}+\mathrm{O}_{2}\right) / \mathrm{W} / \mathrm{O}_{3}$ 型工 マルションが形成されていることが確認された。

\section{$4.2\left(\mathrm{O}_{1}+\mathrm{O}_{2}\right) / \mathrm{W} / \mathrm{O}_{3}$ 型エマルション中の内包物のコントロー ルリリース}

$\left(\mathrm{O}_{1}+\mathrm{O}_{2}\right) / \mathrm{W} / \mathrm{O}_{3}$ 型エマルション中の異なる 3 種の油中に GS 配合し，GSの放出速度を検討した。その結果を図-11に示す。 図より最も GSの放出速度が速いのは, MFD処理により微細化 された $\mathrm{O}_{1}$, 次に $\mathrm{O}_{2}$, そして最外相である $\mathrm{O}_{3}$ であった。この結 果より, $\left(\mathrm{O}_{1}+\mathrm{O}_{2}\right) / \mathrm{W} / \mathrm{O}_{3}$ 型エマルションのそれぞれの油の中に 油溶性成分を配合することで，成分の放出を制御可能なコント ロールリリース機能を付与できることが示唆された。

\section{5. まとめ}

これまでおもに内包する $\mathrm{O} / \mathrm{W}$ 型エマルション中の親水性界面 活性剂量のコントロール，MFDのような高圧乳化機を用いて親 水性界面活性剂の配向状態を変化させることで $\mathrm{O} / \mathrm{W} / \mathrm{O}$ 型エマル ションの分散安定性が向上することを述べた。また $\mathrm{O} / \mathrm{W} / \mathrm{O}$ 型工 マルションをさらに進化させることで新たな機能を付加するこ ともできることを示した。今後も多相エマルションに関するさ らなる研究が行われることを期待している。

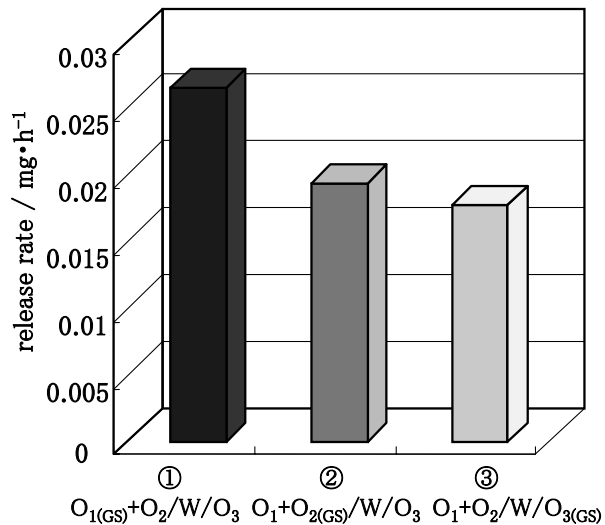

図-11 $\left(\mathrm{O}_{1}+\mathrm{O}_{2}\right) / \mathrm{W} / \mathrm{O}_{3}$ 型エマルションからの GS の放出速度

\section{文献}

1）日本油化学会編：“油化学辞典”, p.384, 丸善 (2004).

2）鷺谷広道，竹ノ内正紀：油化学，30，38（1981）。

3）篠田耕三，日化，89，435 (1968).

4) K. Shinoda, H. Saito : J. Colloid Interface Sci., 30, 270 (1969).

5) H. Saito, K. Shinoda : J. Colloid Interface Sci., 32, 647 (1970).

6) K. Shinoda, H. Saito, H. Arai : J. Colloid Interface Sci., 35, 624 (1971).

7）鈴木裕二，塘久夫：油化学，36，588（1987）。

8) T. Suzuki, H. Takai, S. Yamazaki : J. Colloid Interface Sci., 129, 491 (1989).

9）鈴木裕二，塘 久夫，石田篤郎：日化，337（1983）.

10）鷺谷広道，池田由美子，大郷保治：油化学，33，156 (1984).

11）鴊谷広道，服部孝雄，鍋田一男，永井昌義：日化，1399 (1983).

12) W. Seifriz : J. Phys. Chem., 29, 738 (1925).

13) B. A. Mulley, J. S. Marland : J. Pharm. Pharmacol., 22, 243 (1970)

14) A. Brodin, D. R. Kavaliunas : Acta Pharm. Suec., 15, 1 (1978).

15) J. K. Pandit, B. Mishira : Indian J. Pharm. Sci., 50, 274 (1988).

16) K. Shinoda, H. Saito, H. Arai : J. Colloid Interface Sci., 35, 624 (1971).

17) Matsumoto : J. Colloid. Int. Sci., 94, 362 (1983).

18）山田輝夫：Fragrance Journal，17[4]，107（1989）.

19） Microfluidizer商品カタログ資料，みづほ工業株式会社。

20）高木和行：日本食品工学会年次大会講演要旨集（2001）.

21）高木和行：Fragrance Journal, 26 [8], 84 (1998).

22）高木和行：日本香粧品科学会誌，26〔3]，172（2002）.

23）坊野正代，藤井まき子，中川明子，松本光雄，日本薬剤 学会第 14年会講演要旨集, 77 (1999).

24）中島英夫：表面，36〔1]，39（1998）.

25）岡本亨：Fragrance Journal， 12，30 (2001).

26) P. Walstra : in Encyclopedia Emulsion Technology vol.1, Becher, P. Ed., Marcel Dekker, New York (1983).

27）中島英夫：第49回コロイドおよび界面化学討論会要旨 集, 110 (1996).

28）作山 秀, 福田泰博, 酒井裕二, 中前勝彦：色材, 74〔6], 279 (2001).

29) W. W. Knag, S. Matsumoto : J. Jpn. Oil Chem. Soc., 38, 165 (1989). 


\title{
Approach in the Effective Use of Surfactant for Cosmetic Formulation
}

\author{
Hitoshi IMAMURA $*, \dagger$ \\ * POLA Chemical Industries, Inc. \\ 27-1 Takashimadai, Kanagawa-ku, Yokohama 221-0833, Japan \\ +Corresponding Author, E-mail : imamura@pola.co.jp
}

(Received August 4, 2009 ; Accepted October 27, 2009)

\begin{abstract}
In this report, we controlled quantity of the hydrophilic surfactant maximally by employing minute O/W type emulsion which used high pressure homogenizer for primary emulsification and showed that this method improved stability of the O/W/O type emulsion. We also showed that a polymer surfactant polyoxyethylene (30) dipolyhydroxystearate (PEDS) helped preparing a new $\left(\mathrm{O}_{1}+\mathrm{O}_{2}\right) / \mathrm{W} / \mathrm{O}_{3}$ type emulsion. For the preparation of the new emulsion, O/W/O type emulsion and $\left(\mathrm{O}_{1}+\mathrm{O}_{2}\right) / \mathrm{W}$ type emulsion, where $\mathrm{O}_{1}$ and $\mathrm{O}_{2}$ has different compositions and particle diameters, were combined. A possibility of the control release of the included oil-soluble ingredients in the new emulsion was discussed and effective utilization of surfactants in the $\mathrm{O} / \mathrm{W} / \mathrm{O}$ type emulsion was explained.
\end{abstract}

Key-words : O/W/O type emulsion, Hydrophilic surfactant, High pressure homogenizer, Polymer surfactant, $\left(\mathrm{O}_{1}+\mathrm{O}_{2}\right) / \mathrm{W} / \mathrm{O}_{3}$ type emulsion 